\title{
Communicative-autonomous Teaching: An Innovation in China
}

\author{
Caixia $\mathrm{Hu}$ \\ College of Arts, China University of Petroleum, Qingdao, China \\ Hui He \\ Foreign Languages Department, The Academy of Armored Forces Engineering, Beijing, China
}

\begin{abstract}
Communicative-autonomous Teaching is a new language teaching approach in TESOL. It absorbs the merits of both Communicative Language Teaching and Learner Autonomy Model of Teaching. Adoption of such a method is feasible in China both theoretically and practically. Both the government and the front-line teachers support its application. ' $3+1+x$ ' acts as a good example of practising Communicative-autonomous Teaching in the context of China. ' $3+1+x$ ' is a teaching model centering on the development of students' communicative competence and autonomous learning capacity. Analysis of the teaching materials in China University of Petroleum, including textbooks, handouts and other materials used in the language lab, shows that it is a successful case.
\end{abstract}

Index Terms - communicative-autonomous teaching, innovation, China

\section{INTRODUCTION}

Along with the process of world globalization, China is accelerating its steps of development and strengthening its ties with the outside world. English, as a means of communication, is becoming more and more important. However, there is a widespread recognition that the traditional teaching method can not meet the demand of the society any more. The students can perform well in the written exam but find it difficult to be understood in an interview or in communication with native speakers. Having been accustomed to depending on teachers' instructions, students tend to be passive in learning and do not know how to improve after graduation. In order to solve these problems and to achieve the objectives of the syllabus, a new teaching approach has been adopted in the tertiary teaching, i.e., Communicative-autonomous Teaching Method.

\section{Communicative-Autonomous Teaching In China}

Communicative-autonomous Teaching Method, an innovation in TESOL, is a newly adopted language teaching method in China. It absorbs the merits of both Communicative Language Teaching and Learner Autonomy Model of Teaching.

Communicative Language Teaching (CLT) is an approach that emphasizes both processes and goals in classroom learning (Savignon, 2002). Its central concept is 'communicative competence', a term coined by Dell Hymes in 1966 against Noam Chomsky's distinction between linguistic competence and performance. In 1971, Savignon first used it to describe the ability of students' interaction in the classroom. Keith Johnson and Helen Johnson (1998, p. 62) defined communicative competence as 'the knowledge which enables someone to use a language effectively and their ability actually to use this knowledge for communication'. That means communicative competence refers to not only the knowledge to use language but also the practical skills.

'Communicative language teaching originated from the changes in the British Situational Language Teaching approach dating from the late 1960s' (Razmjoo \& Riazi, 2006). It was introduced into China in 1970s but was not adopted until the recent years. The project of CECL (Communicative English for Chinese Learners) started by two Canadians and a Chinese teacher in Guangzhou in 1979 was our first attempt to base the materials on communicative approach $(\mathrm{Li}, 1984)$. In the process of its development, there were some accounts that valued the adoption of CLT in China (e.g. Li, 1984; Spenser, 1986; Liao, 2004). For example, Li (1984), based on the study of a project, argued that such an approach made language learning an active development process. It also met some resistance (Harvey, 1985). There are, of course, some critical ideas concerning the adoption of CLT in China (Scovel, 1983; Anderson, 1993; Bax, 2003; Liao, 2004). Anderson (1993) evaluated the pros and cons of using communicative language in Chinese context. Bax (2003) argued that teaching should be in accordance to specific contexts, whereas Liao (2004) claimed 'the difficulties caused by situational constraints' could be overcome. It is the argument among the scholars, in the process of putting forward questions, solving them and finding new problems..., that has propelled the development of CLT and has made theoretical preparation for its adoption in China.

With the emergence of CLT, 'autonomy' began to be addressed in the foreign language teaching. Holec (1981) 
defined it as 'the ability to take charge of one's learning' and 'an ability or a capacity that needs to be acquired'. Autonomy was regarded as a 'pedagogical goal' by Wenden (1987) and 'an unavoidable methodological option' by Narcy (1994). It aroused lots of discussion in the western world (Dickinson, 1987; Dam, 1995; Little, 1991). It was introduced into China in 1980s. Some studies have been done in this field (Ho \& Crookall, 1995; Littlewood, 1996; Hua, 2001; Wei, 2002; Xu, et al, 2004). Hua (2001) discussed the teacher roles in the students' autonomous learning. Wei (2002) stressed the necessity and importance of developing students' autonomy in foreign language teaching. Xu, et al. (2004) also put forward some problems in the students' autonomous learning, based on a survey on the college students.

After reviewing research and literature of the theorists, It can be found that both CLT and developing learner autonomy have obstacles when used in China's teaching context. Despite that CLT can promote the interaction between teacher and students in class, there are also some problems in practical language teaching. For example, China usually has big classes, which make it difficult to give each student enough time (Jin, 2007). That's just what autonomous learning can make up for. On the other hand, although autonomous learning encourages students to learn independently, the lack of adequate knowledge and skills prevents them from doing so. Fortunately, that's just what CLT can help. As Littlewood claimed, autonomy is based on 'the ability to use the language creatively' and 'the ability to use appropriate strategies for communicating meanings in specific situations' (Littlewood, 1996, p. 432). From this perspective, we can see CLT and learner autonomy model of teaching can supplement each other. That seems to justify their combination.

Syllabus is an important basis for what method being used in language teaching. China's special context determines the authority of syllabus in teaching. Ministry of Education, the top educational management department, refromulated the syllabus in 2004, stating the objectives of college English teaching is:

培养学生的英语综合应用能力, 特别是听说能力, 使他们在今后工作和社会交往中能用英语有效地进行口头 和书面的信息交流, 同时增强其自主学习能力, 提高综合文化素养, 以适应我国社会发展和国际交流的需要。 (to develop students' comprehensive competence, especially that in listening and speaking so that they can freely communicate in their later work and social communication both orally and in the written form, meanwhile enhancing their autonomous learning capacity and raising their cultural literacy to cater to the needs of development of the society and international communication.)[my translation] (Chinese Ministry of Education, 2004)

The syllabus sets two goals of teaching: one is communicative competence which can be better obtained by using CLT; the other is autonomous learning capacity, which depends much on learner autonomy model of teaching. Therefore, to achieve these two goals, the two teaching approaches have to be combined together.

What's more, College English Test Band 4 (CET-4) is another factor that determines the language teaching method in universities. It's a very important test to the university students. 'Many universities have refused to grant a Bachelor's degree to those who fail the test', claimed by Zhang (2005), 'and many companies and government agencies have refused to accept applicants without test certificates'. CET-4, a nationwide, standardized English test, was reformed in 2004 to cater to the new syllabus. The new test canceled the grammar structure and the usage of words, and added fast reading part. The scale of listening increased to $35 \%$ from $20 \%$ (Zhang, 2005). From this, we can see the new CET-4 has shifted the focus from testing knowledge to testing competence. Accordingly, the universities have to change the teaching method, considering its importance to the university students.

Working in the front line, many teachers began to realize weaknesses of the traditional teaching method. They were eager to find a new way to change the situation. The traditional approaches to language teaching put stress on the grammar and vocabulary input. 'They were based on the belief that grammar could be learned through direct instruction and through a methodology that made much use of repetitive practice and drilling' (Richards, 2005). So, the most commonly used technique was asking students to recite words or drills and reproduce new sentences. The main activity in class is in the question-answer form: Teacher initiates questions and students answer together or individually. That's a typical cramming method of teaching. Students were presented with a lot of information concerning grammar rules and usage of words in class. There's a very vivid comparison, saying, 'the traditional way of teaching English in China is just like trying to teach people to swim without getting in the water'(Zhang, 2005). Therefore, the outcome of this method is that students 'have learned lots of grammar rules, [but] when using English to communicate, they will make grammatical mistakes frequently' (Jin, 2007). Without teachers' instructions, the students did not know what to learn, let alone how to learn.

As can be seen from the discussion above, lots of theoretical studies had been done. Both government and the front-line teachers supported reform in language teaching. The change of teaching method in college English had become an inevitable trend. It is in such a situation that the communicative-autonomous teaching method was born. So, it can be argued that roots of the innovation are both in theory and practice.

\section{III. ' $3+1+X$ ': A SuCCESSFUl Model in Practising COMMUNiCATIVE-AUTONOMOUS TEACHING}

Under the guidance of the new syllabus, China university of Petroleum quickly threw itself into the stream of practising the innovation. A new teaching model named ' $3+1+x$ model' was put forward. It turns out to be a successful example of applying the communicative-autonomous teaching method.

' $3+1+x$ ' is a teaching model centering on the development of students' communicative competence and autonomous learning capacity. In the model, 2 weeks is considered as a unit: ' 3 ' stands for 3 hours' intensive reading class, ' 1 ' means 1 hour's speaking and listening class, ' $x$ ' is the time for students to do autonomous learning by using the facilities of the 
university. This model, with the help of multimedia and internet technology, attempts to make College English a new system focusing on not only teachng knowledge, but also skills, learning strategies, and cross-cultural communication.

The application of the communicative-autonomous teaching method can be reflected in every stage or aspect of the new teaching model. Teaching materials are the most representative one. As Barker and Matveeva (2006, p.192) mention, teaching materials 'represent the main content and teaching techniques that an individual teacher might use'. Here is a detailed analysis of the different kinds of teaching materials used in China University of China.

\section{A. Textbooks}

'Textbooks play a very crucial role in the realm of language teaching and learning...' (Riazi, 2003, p. 52) Cortazzi and Jin (1999) define the role of a textbook as 'a trainer' that provides teachers with explanation and guidance, 'a teacher' that gives students direct instructions, and 'a map' which shows an overview of structured cultural elements, etc. In the traditional language teaching, 'textbooks serve as the basis for much of the language input learners receive', whereas in the new language teaching model, they provide 'the balance of skills taught, and the kinds of language tasks students acively use'. (Razmjoo, 2007) When the ' $3+1+x$ ' teaching model was first practiced in the university, the revised version of 'New College English' was used as the textbook. In the new version, more activities have been added and the texts have been changed into much more useful ones to keep step with the development of the outside world. The preparation part of each unit gives much more background information by providing more activities such as description of pictures, brainstorming words, etc. As is mentioned in the preface, the aim of this book is:

在遵循现代外语教学理念、充分利用先进信息技术的基础上, 注重为学生创造自主学习环境, 强调个性化学 习, 全面培养学生的英语综合应用能力, 尤其是听说能力, 使他们在今后工作和社会交往中能用英语有效地进 行口头和书面的信息交流 (under the guidance of modern language teaching, on the basis of making full use of advanced information technology, put stress on creating autonomous learning environment for students to do personalized study, developing students' comprehensive competence, especially that in listening and speaking so that they can freely communicate in their later work and social communication both orally and in the written form.) [my translation] (Ying, 2004)

\section{B. Handouts}

In China University of Petroleum, supplementary materials are usually worked out by the teachers collectively to aid teaching. They are usually printed in the form of handouts and assigned to every teacher a copy. Here is a comparison between the two copies of handouts in different teaching models. Distinction can be clearly seen in the same unit of the same book (Unit 1, Book 1) as shown in Table 1.

TABLE 1.

COMPARISON BETWEEN TRADITIONAL MODEL AND 3+1+XMODEL

\begin{tabular}{|c|c|c|c|c|c|c|c|}
\hline Comparison & Model & $\begin{array}{c}\text { Vocabulary\& } \\
\text { Grammar }\end{array}$ & Listening & Speaking & Reading & Translation & Writing \\
\hline \multirow{2}{*}{$\begin{array}{l}\text { Proportion } \\
\text { (\%) }\end{array}$} & traditional(\%) & 60 & 5 & 5 & 15 & 10 & 5 \\
\hline & $3+1+x(\%)$ & 5 & 30 & 30 & 25 & 5 & 5 \\
\hline \multirow{2}{*}{$\begin{array}{l}\text { Main } \\
\text { Parts } \\
\text { Used to } \\
\text { Develop } \\
\text { the Ability }\end{array}$} & traditional & $\begin{array}{l}\text { Word \& } \\
\text { Sentence } \\
\text { Analysis, } \\
\text { Summary, } \\
\text { Supplementary } \\
\text { Exercises }\end{array}$ & Spot Dictation & $\begin{array}{l}\text { Making up } \\
\text { Sentences } \\
\text { in the } \\
\text { Vocabulary } \\
\text { Analysis }\end{array}$ & Text Analysis & $\begin{array}{l}\text { Sentence } \\
\text { Translation, } \\
\text { Paragraph } \\
\text { Translation }\end{array}$ & Composition \\
\hline & $3+1+x$ & $\begin{array}{l}\text { Words in } \\
\text { Context }\end{array}$ & $\begin{array}{c}\text { Listening } \\
\text { Comprehension, } \\
\text { Summary }\end{array}$ & $\begin{array}{l}\text { Lead-in } \\
\text { Activities, } \\
\text { Discussion }\end{array}$ & $\begin{array}{c}\text { Text Analysis, } \\
\text { Supplementary } \\
\text { Exercises }\end{array}$ & $\begin{array}{l}\text { Sentence } \\
\text { Translation }\end{array}$ & $\begin{array}{l}\text { Summary, } \\
\text { Composition }\end{array}$ \\
\hline
\end{tabular}

As can be seen from the table, in the traditional teaching, $60 \%$ of the material was used to deal with grammar and vocabulary, whereas the proportion aiming to develop listening and speaking altogether was only $10 \%$. So, the reason why people usually call it 'dumb English' is quite clear. In contrast, in the new teaching, only 5\% centers on the grammar and vocabulary. More efforts are put on the cultivation of listening, speaking and reading abilities, with the 
proportion going to each almost equally. Faerch's words seem to justify the proportion of different parts in the new material: 'Communicative competence in fact covers listening and reading as well as speaking and writing' (Faerch et al, 1984). As to the writing part, the distinction seems not to be so clear in this table. Actually that's just what is usually put in ' $x$ ' part. There are lots of writing materials in the language lab for the students to use. Students can access them in the autonomous learning time and can practice there by using the modern system. Every two weeks, students are required to submit at least one piece of writing. For each, the teachers will quickly give feedback online or individually.

From comparison between the old material and the new one, it can easily be seen that there are not many activities in the old material. It seems that almost all the stages of teaching should serve for illustrating the usage of words. Before dealing with each passage, there is always a list of words or phrases for students to grasp in different level: some for recitation and some for comprehension. Even in the analysis of the text, the stress is still put on the words instead of the structure or the information of the passage. One more weak point reflected in the old material is that teachers do not use multimedia. Even in the spot dictation part, they have to read the text to the students. In sharp contrast, the new materials, with help of multimedia, provide more varieties: lead-in activities, listening comprehension, words in context, etc. In the new teaching model, even when guiding students to understand the usage of some words, teachers show the context instead of telling the students the usage directly. The different items in the supplementary exercises also clearly show a shift of focus away from the traditional way. As to the different functions of each part, they can be roughly shown in the table above (table 1).

\section{Materials Used in the Language Lab}

Materials in the language lab are mainly authentic materials and are used for both 'listening and speaking' class and students' autonomous learning. Gebhard (1996) sees authentic materials as a way to 'contextualize' language learning. When lessons are centered on comprehending a menu or a TV weather report, students tend to focus more on content and meaning rather than the language itself. This offers students a valuable source of language input, so that they are not being exposed only to the language presented by the text and the teacher.

In 'listening and speaking' class, besides the materials for listening comprehension, there are lots of discussion topics to guide students to say something. Facilities in the language lab provide the convenience for students to discuss with others even if they sit far away. What they need to do is clicking somebody who is interested in the same topic, then they will be in the same group. During their discussion, the teacher can monitor and can interrupt when necessary. Such facilities create opportunities to realize free communication in class between teacher and students or among students themselves.

Some labs are open to students every day, including the weekends. The students can go there to do autonomous learning at any time when they feel like. This is a unique characteristic of the ' $3+1+x$ model'. 'Learner autonomy' as Bergen (1990, p. 59; cited in Dam, 1995, p. 1-2) pointed out, 'is characterized by a readiness to take charge of one's own learning in the service of one's needs and purposes.' ' $X$ ' serves well in this aspect. It fully depends on the students as to when and how long to learn. There the students also have the opportunity to select what they want to learn and what they need to learn. Lots of materials are available in the labs to cater to the students of different level: textbooks with detailed explanation and audio-visual courseware, listening exercises, exam papers of the previous years, items for translation, reading exercises, writing materials, items for spoken English practice, videos, and films, etc. Of course, there are certain assignments for the students to finish online. Considering that some students may not voluntarily do autonomous learning, a minimum amount of time has been set to ' $x$ ', that is, 3 hours every two weeks. And a very good monitoring system has been made.

From the above analysis, ' $3+1+x$ model' is a good example to practise Communicative-autonomous Teaching Method. It can clearly achieve the goal of fostering the students' communicative competence and developing their autonomous learning capacity. Teaching results also show that it is a successful case.

\section{CONCLUSION}

Communicative-autonomous Teaching Method, an innovation in TESOL, was born with development of the communicative language teaching theory and the theory of autonomy. The research done in these two fields made some theoretical preparation for the adoption of this method in China. On the other hand, some factors in practice also contributed to its birth, such as reformulation of syllabus, reform of the nationwide test and findings of the front-line teachers, etc. So, it can be argued that its roots are both in theory and practice. Communicative-autonomous Teaching Method aims to develop students' both communicative competence and autonomous learning capacity. It's a shift of focus from the traditional teaching, which mainly centered on grammar and vocabulary. This paper uses a new teaching model ' $3+1+x$ ' in China University of Petroleum as an example to show how the innovation is used in practice. From comparison of the old and the new materials, the weaknesses of the traditional teaching and the strengths of the innovation can be clearly seen.

\section{REFERENCES}

[1] Anderson, J. (1993). Is the communicative approach practical for teaching English in China? Pros and cons, 21, 417-480.

[2] Barker, T. and N. Matveeva. (2006). Teaching intercultural communication in a technical writing service course: real 
instructors' practices and suggestions for textbook selection. Technical Communication Quarterly, 15(2), 191-214.

[3] Bax, S. (2003). CALL - past, present and future. System, 31(1), 13-28.

[4] Chinese Ministry of Education. (2004). College English Curriculum Requirement (trial) http://www.edu.cn/20040120/3097997.shtml (accessed 11/7/2013).

[5] Cortazzi, M. and L. Jin. (1999). Cultural mirrors: materials and methods in the EFL classroom. In E. Hinkel (ed.) Culture in Second Language Teaching and Learning. Cambridge: Cambridge University Press, 197-217.

[6] Dam, L. (1995). Learner Autonomy: from Theory to Classroom Practice. Dublin: Authentik.

[7] Dickinson. L. (1987). Self-Instruction in Language Learning. Cambridge: Cambridge University Press.

[8] Faerch C., Harastrup K. and Phillipson. (1984). Learner Language and Language Learning. London: Mulrilingual Matters Ltd.

[9] Gebhard, J.G. (1996). Teaching English as a Foreign Language: A Teacher Self-Development and Methodology Guide. Ann Arbor: The University of Michigan Press.

[10] Harvey, P. (1985). A Lesson to be learned: Chinese approaches to language learning. ELT Journal 39, 7-9.

[11] Ho, J. \& D. Crookall. (1995). Breaking with Chinese cultural traditions: Learner autonomy in English language teaching. System, 23(2), 235-243.

[12] Holec, H. (1981). Autonomy and Foreign Language Learning. Oxford: Pergamon Press.

[13] Hua, W.F. (2001). Teachers' roles in learner autonomy. Journal of Foreign Language Research, 3, 76-79.

[14] Jin, Y. (2007). Adapting communicative language teaching approach to China's context. Sino-US English Teaching, 4 (10), 29-33.

[15] Johnson, K. \& H. Johnson. (1998). Encyclopedic Dictionary of Applied Linguistics. Oxford: Blackwell Publishers.

[16] Liao, X.Q. (2004). The need for Communicative Language Teaching in China. ELT Journal 58(3), 270-273.

[17] Li, X.J. (1984). In defense of the Communicative Approach. ELT Journal 38, 2-13.

[18] Little, D. (1991) Learner Autonomy: Definirions,. Issues and Problems. Dublin: Authentik.

[19] Littlewood, W. (1996). "Autonomy": an anatomy and a framework. System, 24 (4), 427-435.

[20] Narcy, J. P. (1994). Autonomie: Evolution ou révolution. Die Neuere Sprache, 93(5), 430-441.

[21] Richards, J. C. (2005). Communicative language teaching today. Singapore: SEAMEO Regional Language Centre.

[22] Razmjoo, S. A. (2007). High schools or private institutes textbooks? Which fulfill Communicative Language Teaching principles in the Iranian context? Asian EFL Journal, 9 (4), 126-140.

[23] Razmjoo, S.A., \& A.M. Riazi. (2006). Is Communicative Language Teaching practical in the expanding circle? --A case study of teachers of Shiraz high schools and institutes. Journal of Language and Learning,4 (2), 144-171.

[24] Riazi, A. M. (2003). What textbook evaluation schemes tell us? A study of the textbook evaluation schemes of three decades. In W. A. Renanda. (ed.), Methodology and materials design in language teaching. Singapore: SEAMEO Regional Center, 52-68.

[25] Savignon, S. J. (2002). Interpreting Communicative Language Teaching: Contexts and Concerns in Teacher Education. New Haven: Yale University Press.

[26] Scovel, T. (1983). The impact of foreign experts, methodology and materials on English language study in China. Language Learning and Communication. 2(1), 83-91.

[27] Spenser, L. (1986). An adjunct-model English-language Program in Beijing. Monday Morning / Lundi Matin. 2(1), 7-9.

[28] Wei, Y. Y. (2002). Learner autonomy: a new concept of foreign language teaching. Foreign Language World, 3, .8-14.

[29] Wenden, A. (1987). How to be a successful language learner: Insights and prescriptions from L2 learners. In A. Wenden\& J. Rubin (eds.), Learner Strategies in Language Learning. London: Prentice Hall, 103-117.

[30] Xu, J. F., R. Z.Peng, and W.P. Wu. (2004). Survey and analysis on the autonomous learning ability of non-English majors. Foreign language Teaching and Research, 1, 64-68.

[31] Ying, H.L. (2004) New College English (2nd edn.). Beijin: Foreign language Teaching and Research Press.

[32] Zhang Y. (2005). Meeting highlights English teaching reform. China Daily, http://www.chinadaily.com.cn/english/doc/2005-11/08/content_492169.htm (accessed 13/7/2013).

Caixia Hu is a lecturer at College of Arts, China University of Petroleum, China. Her research interests mainly include EFL teaching and learning in China's context, and literature.

Hui He is a lecturer at Foreign Languages Department, The Academy of Armored Forces Engineering, China. Her research interests mainly include Applied Linguistics and English teaching. 